\title{
POPULATION DYNAMICS AND AQUACULTURE POTENTIAL OF THE MUD CLAM, Geloina expansa (MOUSSON, 1849) (BIVALVIA: CYRENIDAE) IN LOAY-LOBOC RIVER, BOHOL, CENTRAL PHILIPPINES
}

\author{
FRANCIS ALBERT TABO ARGENTE ${ }^{1,2^{*}}$ AND ANTHONY ILANO ${ }^{1}$ \\ ${ }^{1}$ Department of Biology, University of San Carlos - Talamban Campus, Cebu City, Cebu, 6000 Philippines. ${ }^{2}$ Center for \\ Hydrology, Aquaculture, Natural and Ocean Sciences (CHANOS), Pangasinan State University-Binamley Campus, \\ Binmaley, Pangasinan, 2417, Philippines
}

*Corresponding author: francisargente@psu.edu.ph

Submitted final draft: 13 Jun $2020 \quad$ Accepted: 25 Jun 2020

http://doi.org/10.46754/jssm.2021.04.004

\begin{abstract}
The status of the mud clam, Geloina expansa, an important bivalve in the artisanal fisheries of the Loay-Loboc River, was assessed using monthly shell length frequency data (October, 2012 to January, 2015) to estimate population parameters. Growth parameters derived were $\mathrm{L}_{\infty}=91.35 \mathrm{~mm}, \mathrm{~K}=0.75 \mathrm{yr}^{-1}$ and $\mathrm{t}_{0}=-0.16$. Predicted $\mathrm{L}_{\max }$ was $90.39 \mathrm{~mm}$. Estimated growth rates showed fast growth for the first two years. Longevity is approximately 6.1 years. Length-weight relationship showed a positive allometric growth $\left(r^{2}=0.94\right)$. The estimated total mortality $(\mathrm{Z})$ was $2.89 \mathrm{yr}^{-1}$. Natural $(\mathrm{M})$ and fishing (F) mortalities estimates were $0.90 \mathrm{yr}^{-1}$ and $1.99 \mathrm{yr}^{-1}$, respectively. Estimated exploitation rate $(\mathrm{E}=0.69)$ was higher than the maximum sustainable exploitation $\left(\mathrm{E}_{\max }=\right.$ 0.41). Two annual recruitment peaks occurred during the months of December to February and July to August. Monthly condition index (CI) suggested that spawning is year-round. It appeared that the variations in CI of G. expansa in the river was influenced by the water temperature and salinity $\left(r^{2}=0.54 ; P<0.0001\right)$. These biological information may be used for aquaculture technique development for $G$. expansa in central Philippines which will aid in the conservation and management of natural stocks.
\end{abstract}

Keywords: Bivalve, Nypa, FiSAT II, estuarine, conservation.

\section{Introduction}

In 2019, the world population was estimated to be more than 7.7 billion, which is a 1 billion increase from the 2007 estimate (United Nations, 2019). The rising human population created mounting pressure on global food security (Misselhorn et al., 2012; Frona et al., 2019). Aquaculture is deemed as one of the potential mechanisms to address this perennial problem (Bene et al., 2016; Pradeepkiran, 2019). However, the aquaculture industry itself may be in a critical state due to the changing climate (Hall, 2015; Reid et al., 2019).

Several cultivable invertebrate species have shown signs of vulnerability to the changing environmental conditions (Ahmed \& Diana, 2015; Dworjanyn \& Byrne, 2018; Steeves et al., 2018). One of the proposed measures to mitigate the negative effects of climate change in the aquaculture industry is the search for new and better adapted species (D'Abramo \& Slater, 2019). Members of the mud clam genus Geloina
(Polymesoda) have been reported to be resilient to adverse environmental conditions (Morton, 1976; Gimin et al., 2004; Argente et al., 2014). This feature makes these mud clams potential candidates for aquaculture. Hence, gaps in the biological information of this genus should be addressed in order to develop cultivation techniques. This will eventually aid in the conservation and artificial production of these mud clams.

The mud clam, Geloina expansa (Figure 1), is one of the common bivalve species found in the Nypa zones of Loay-Loboc River in Bohol, Philippines. It is a suspension filter-feeder which burrows in muddy bottoms of brackish water ranges (Hiong, et al., 2004). G. expansa plays a significant role as a bioremediation agent, having the capacity to accumulate various heavy metals (Chuan et al., 2017) and persistent organic pollutants (Bayen et al., 2005) in its environment. Economically, G. expansa may be a potential source of antimicrobial drugs 
(Argente \& Ilano, 2015). At the moment, the $G$. expansa population in Loay-Loboc River is subject to artisanal fishery for small-scale commercial and sustenance consumption of the local residents.

The artisanal fishery of G. expansa in LoayLoboc River is carried out in the Nypa zones of the river. This activity is either for family consumption or secondary source of income for the community. Gleaning is done daily during low tide where clams are easily located. Gleaners use bare hands in harvesting the clams. The fishery is year-round and usually peaks on the onset of the rainy season. At the moment, there is no regulation on the fishery for $G$. expansa in Loay-Loboc River.

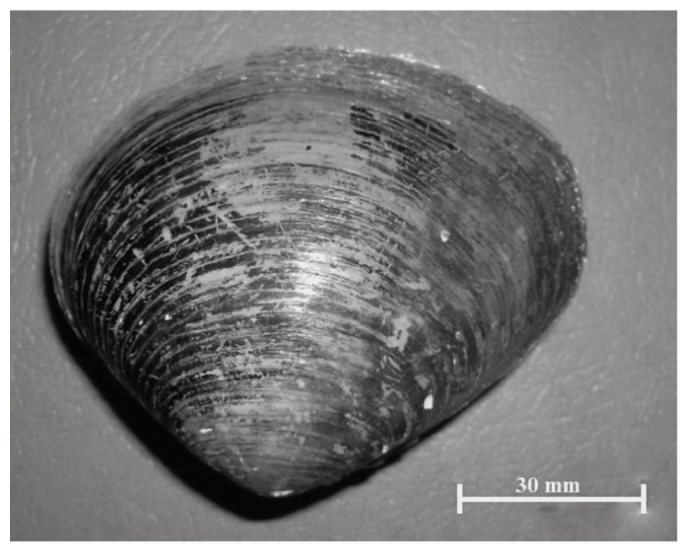

Figure 1: G. expansa from Loay-Loboc River, Bohol, Philippines

Given the importance of $G$. expansa, little is known on the biology and status of natural populations of this bivalve. Information on the population dynamics of bivalve species is significant in assessing its aquaculture potential (Stern-Pirlot \& Wolff, 2006; Adjei-Boateng \& Wilson, 2012; Argente et al., 2014). It can also convey vital facts for the management of a particular bivalve population (Del NorteCampos \& Villarta, 2010; Dolorosa \& DanganGalon, 2014; Argente \& Estacion, 2014). Population dynamics depict the means in which a given population develops and drops over time as regulated by birth, death, and recruitment. It serves as a basis for recognizing the varying fishery patterns and concerns, like habitat degradation, predation and ideal harvesting rates. Studies on the population biology of $G$. expansa are needed to prelude the development of culture techniques and to facilitate adequate stock management.

This study was conducted to assess some aspects of population growth, mortality and recruitment of $G$. expansa. It provides baseline biological information for future culture technique development in central Philippines.

\section{Materials and Methods}

Clams used in this study were collected from the Nypa zones of Masayon, Loay-Loboc River, Bohol, Philippines $\left(9.60853^{\circ} \mathrm{N}, 124.01265^{\circ} \mathrm{E}\right)$. The area is a known gleaning site for mangrove bivalves. The river has estuarine hydrologic characteristics, which is an ideal site for $G$. expansa since this species is a known brackishwater dweller (Hiong et al., 2004). The clam bed is characterized with a muddy substrate.

Eighty clams were collected monthly (October, 2012 to January, 2015) with the assistance of a commissioned bivalve gleaner. The sampling site (1ha area) was established with the help of local gleaners. Sampling was done every last week of the month during low tide to easily find the area where the clams aggregate. The commissioned gleaner used bare hands to collect samples. There was no size discrimination of $G$. expansa individuals during the sampling.

Collected clams were placed in prelabeled net bags and brought to the University of San Carlos-Marine Biology Laboratory for processing. Shell length of the clams was measured using a digital Vernier caliper $(0.01$ $\mathrm{mm}$ precision) and recorded to construct a monthly length frequency data. Shell length was measured as the distance from the anterior to the posterior axis of the shell (Lomovasky et $a l ., 2005)$. The monthly length frequency data were used to determine growth, mortality and recruitment parameters with the help of FiSAT 
II (FAO-ICLARM Stock Assessment Tools) program package (FAO, 2020).

Growth of the $G$. expansa population was assumed to be described by the von Bertalanffy growth function (VBGF) (Sparre \& Venema, 1998). Growth parameters such as the asymptotic length $\left(\mathrm{L}_{\infty}\right)$ and growth coefficient $(\mathrm{K})$ were estimated using the ELEFAN I (Electronic Length Frequency Analysis). $\mathrm{L}_{\infty}$ is interpreted as the mean length of a very old species, while $\mathrm{K}$ is the rate at which determines how fast the species approaches its $\mathrm{L}_{\infty}$ (Sparre \& Venema, 1998). The initial condition parameter $\left(t_{0}\right)$ was estimated applying the formula used for other bivalves (Hariyadi et al., 2017; Fauzan et al., 2018; Solis et al., 2019). In theory, $\mathrm{t}_{0}$ determines the point in time when the organism has zero length.

$$
\log \left(-t_{0}\right)=-0.3922-0.2752 \log \left(L_{\infty}\right)-1.038 \log (K)
$$

Moreover, annual growth rates were estimated based on the VBGF model (Sparre \& Venema, 1998).

$$
\frac{\Delta L}{\Delta t}=K x\left(L_{\infty}-L(t)\right)
$$

Where $\frac{\Delta L}{\Delta t}$ is the growth rate and is the length at age $\mathrm{t}$.

The longevity $\left(\mathrm{t}_{\max }\right)$ of $G$. expansa population in the river was derived following the stadard equation used for bivalve species (Corte et al., 2015). The life span was predicted by an inverse VBGF formula, with the assumption of maximum length equal to $99 \%$ of the asymptotic length.

$$
\mathrm{t}_{\max }=\frac{\left[\operatorname{In} \operatorname{In} L_{99 \%}-\operatorname{In} \operatorname{In}\left(L_{\infty}-L_{99 \%}\right)\right]}{K}
$$

The shell length-total weight relationship was established through regression analysis. Correlations were based on the size-weight relationship formula used for clams (Colakoglu \& Palaz, 2014; Yahya et al., 2018; Petteta et al., 2019):

$$
W=a L^{b}
$$

Where $W$ is the weight $(\mathrm{g}), L$ is the length ( $\mathrm{mm})$, $a$ is the multiplicative factor of the species and $b$ is the slope. The relationship established was used to interpret if the weight growth was isometric or allometric in relation to its growth in size. When $b=3$, weight growth is isometric while when $b \neq 3$, weight growth is allometric (positive if $\mathrm{b}>3$, negative if $\mathrm{b}<3$ ) (Petteta et al., 2019).

The predicted maximum length $\left(\mathrm{L}_{\max }\right)$ of $G$. expansa in the population was estimated based on the largest specimen sampled with the aid of the FiSAT II program.

The rate of total mortality (Z) of G. expansa population in the river was estimated from a length-converted catch curve using pooled monthly length-frequency data. The $\mathrm{Z}$ relates to the negative slope of the linear regression of the descending arm of the catch curve (Argente \& Estacion, 2014). Estimation of natural mortality (M) was done using the method described by Argente and Estacion (2014), where the average of $\mathrm{M} / \mathrm{K}$ values from Polymesoda (Geloina) species in literature was multiplied with that of the estimated $\mathrm{K}$ value from this study. By subtracting $\mathrm{M}$ from $\mathrm{Z}$, fishing mortality (F) was derived. Exploitation rate (E) was projected by dividing the $\mathrm{F}$ by $\mathrm{Z}$. The exploitation rate producing maximum yield $\left(\mathrm{E}_{\max }\right)$ was also estimated with the aid of the FiSAT II program and compared with the current estimation of $\mathrm{E}$ to assess the status of the fishery.

Recruitments patterns for $G$. expansa were derived through a monthly length-frequency data. The size range of the samples was from $18.56 \mathrm{~mm}$ to $90.55 \mathrm{~mm}$ and individual clams were grouped into 3-mm size classes. Recruitment peaks were observed by documenting the months with the most number of small clams $(<$ $40 \mathrm{~mm}$ ).

Thirty clams were collected monthly from the study site to determine the condition index (CI) of the G. expansa population in the river. CI was used to establish the time of spawning of the clams. The CI of G. expansa had been reported to show direct correlation with its reproductive cycle (Rahim et al., 2012). To determine CI, internal shell capacity (ISC) and dry weight of 
the soft tissues were obtained. The calculation of CI for the G. expansa population was based on the formula used by Ilano et al. (2007):

$$
C I=\frac{w w}{I S C} \times 1000
$$

Where $w w$ is the wet weight of the soft tissue and $I S C$ is the internal shell capacity derived from the difference between the total weight and shell weight.

Water temperature and salinity were monitored on a weekly basis for the duration of the study. Recording of the parameters were done three times $(5 \mathrm{am}, 12 \mathrm{pm}$ and 6 $\mathrm{pm}$ ) during the day of monitoring. Monthly water temperatures were recorded based on the readings of a laboratory thermometer. Monthly salinity measurements were done with the use of a field refractometer. Stepwise multiple regression analysis was used to determine the influence of these environmental parameters on the monthly variations of $\mathrm{CI}$ in the population of $G$. expansa in the river. The significance level was set at $\mathrm{P} \leq 0.05$.

\section{Results and Discussion}

The derived VBGF parameters from the monthly length frequency data (Figure 2) were $\mathrm{L}_{\infty}=91.35 \mathrm{~mm}, \mathrm{~K}=0.75 \mathrm{yr}^{-1}$ and $\mathrm{t}_{0}=-0.16$ for the G. expansa population in Loay-Loboc River.

Fast growth in the G. expansa population was observed up to two years of age, with a mean growth rate of $21.13 \mathrm{~mm} \mathrm{yr}^{-1}( \pm 10.71$ $\mathrm{SD}$ ) (Figure 3). Moreover, the majority of the samples $(87.10 \%)$ were less than two years old $(<61 \mathrm{~mm})$ in age. The estimated longevity $\left(\mathrm{t}_{\max }\right)$ was 6.1 years while $\mathrm{L}_{\max }$ was $90.39 \mathrm{~mm}$.

The length-weight relationship established for $G$. expansa indicated a positive allometric growth (Figure 4).

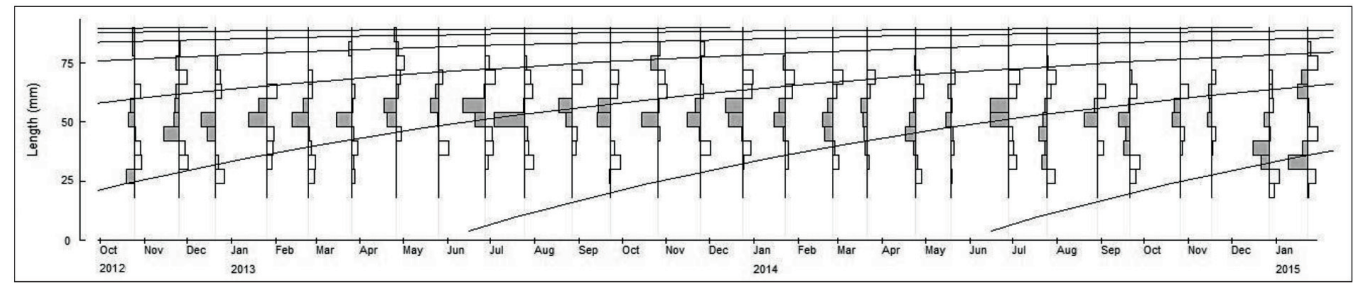

Figure 2: Restructured length-frequency data of $G$. expansa population in Loay-Loboc River with superimposed growth curve estimated by ELEFAN I $\left(\mathrm{L}_{\infty}=91.35 \mathrm{~mm} ; \mathrm{K}=0.75\right.$ year $\left.^{-1} ; \mathrm{t}_{0}=-0.16\right)$

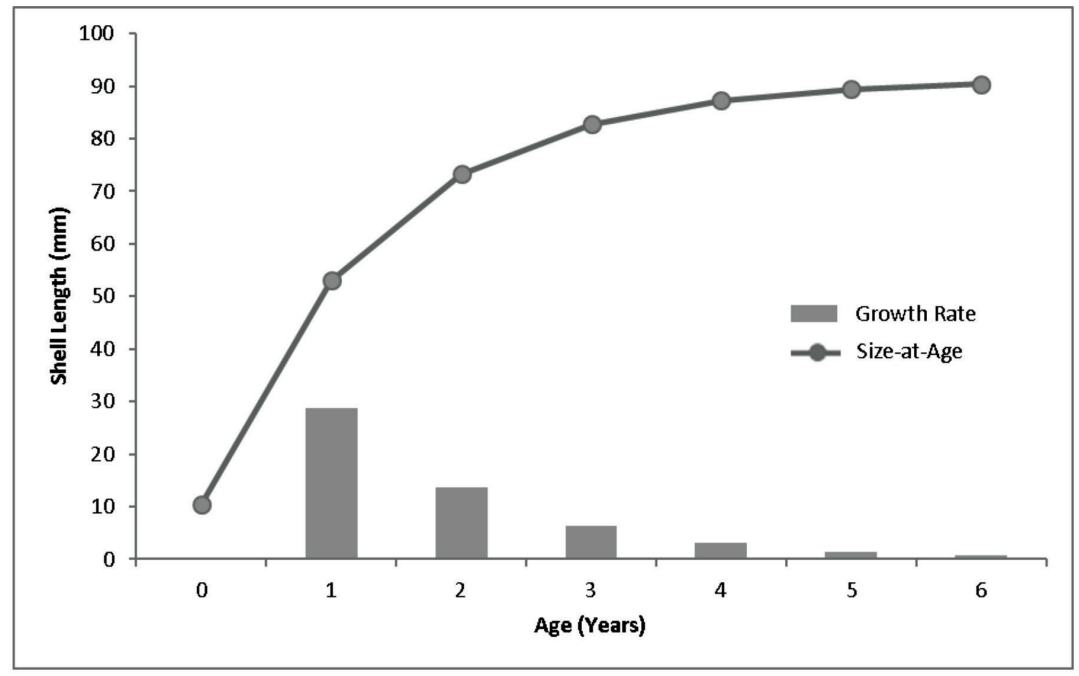

Figure 3: Size-at-age and growth rates of $G$. expansa population in Loay-Loboc River 


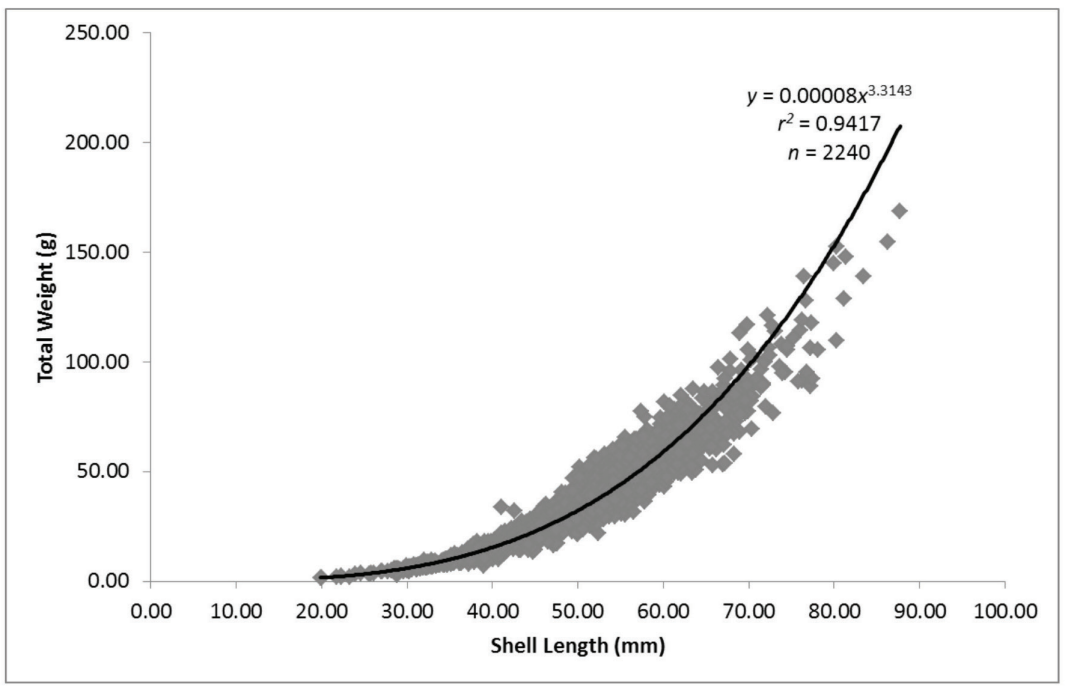

Figure 4: Length-weight relationship of G. expansa population in Loay-Loboc River

Based on the length converted catch curve (Figure 5), $\mathrm{Z}$ was $2.89 \mathrm{yr}^{-1}$. The $\mathrm{M} / \mathrm{K}$ values derived from other Polymesoda (Geloina) species (Table 1) indicated that the $\mathrm{M}$ for $G$. expansa population in Loay-Loboc River was $0.90 \mathrm{yr}^{-1}$. It follows that $\mathrm{F}$ and $\mathrm{E}$ were $1.99 \mathrm{yr}^{-1}$ and 0.69 , respectively. The estimated $\mathrm{E}_{\text {max }}(0.41)$ was higher than $\mathrm{E}$.

Based on the monthly length-frequency data (Figure 6), recruitment of $G$. expansa is yearround. It also appeared that there are two peaks of recruitment in the population, which occurs every December to February and July to August. On the other hand, the monthly mean CI of $G$. expansa population in the Loay-Loboc River revealed a complementary spawning pattern to that of recruitment (Figure 7A). Reduced CI values, which indicated spawning activities,

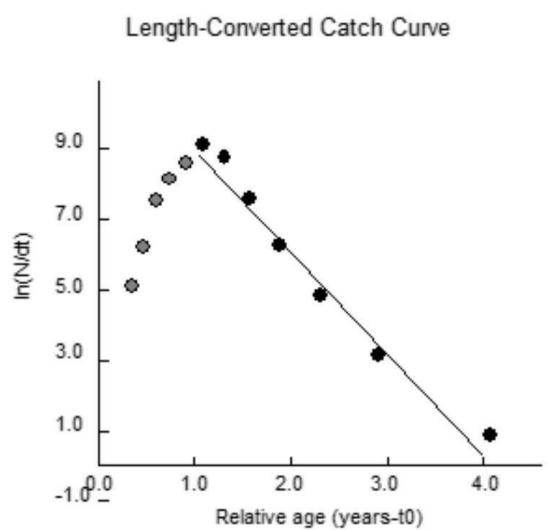

Figure 5: Length converted catch curve $\left(r^{2}=0.98\right)$ of G. expansa population in Loay-Loboc River used to estimate total instantaneous mortality $(\mathrm{Z})$

were observed from the months before the peak recruitment.

Table 1: Natural mortality $\left(\mathrm{M}, \mathrm{yr}^{-1}\right)$ and growth coefficient $\left(\mathrm{K}, \mathrm{yr}^{-1}\right)$ literature estimates of different Polymesoda species used to compute the $\mathrm{M}$ value of $P$. expansa population in Loay-Loboc River

\begin{tabular}{lcccl}
\hline Polymesoda species & $\mathbf{M}$ & $\mathbf{K}$ & $\mathbf{M} / \mathbf{K}$ & \multicolumn{1}{c}{ Source } \\
\hline P. solida & 0.210 & 0.204 & 1.029 & Rueda \& Urban, 1998 \\
P. erosa & 1.410 & 1.000 & 1.410 & Dolorosa \& Dangan-Galon, 2014 \\
G. expansa & 1.100 & 0.700 & 1.571 & Yahya et al., 2018 \\
P. erosa & 0.760 & 0.760 & 1.000 & Ransangan et al., 2019 \\
P. expansa & 0.820 & 0.820 & 1.000 & Ransangan et al., 2019 \\
\multicolumn{1}{c}{ Mean } & & & $\mathbf{1 . 2 0 2}$ & \\
\hline
\end{tabular}




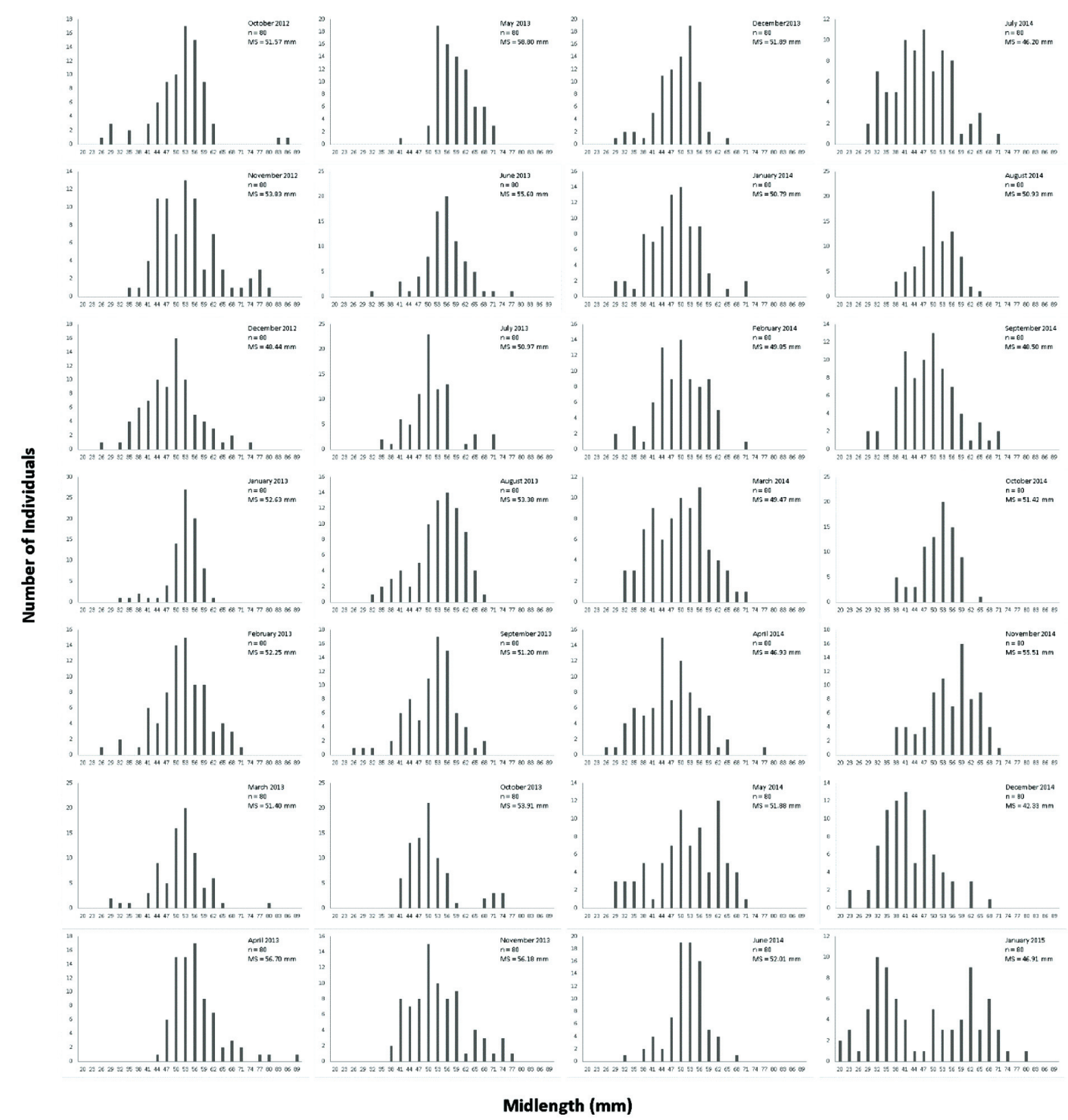

Figure 6: Monthly length-frequency distribution of G. expansa population in Loay-Loboc River. n: number of individuals; MS: mean size of individuals 

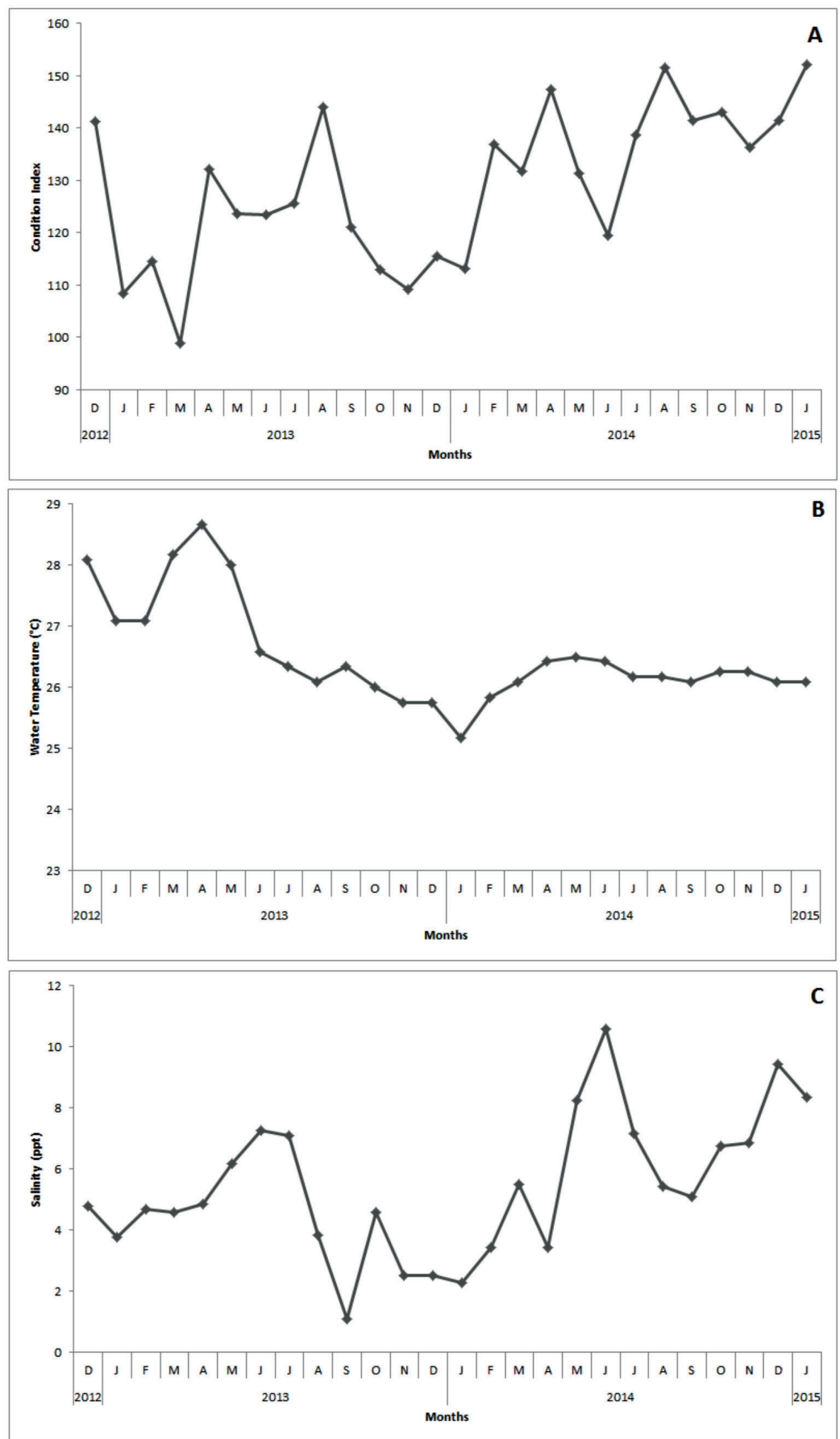

Figure 7: Mean condition index (A) of G. expansa population and mean water temperature (B) and salinity (C) in the clam bed in Loay-Loboc River 
Monthly mean values of water temperature (Figure 7B) and salinity (Figure 7A) in the $G$. expansa clam bed ranged from 25.17 to $28.67^{\circ} \mathrm{C}$ and 1.08 to $10.58 \mathrm{ppt}$, respectively. The recorded annual mean water temperature was 26.52 ${ }^{\circ} \mathrm{C}( \pm 0.31 \mathrm{SD})$ while the annual mean salinity was $5.39 \mathrm{ppt}( \pm 2.32 \mathrm{SD})$. These environmental parameters contributed to the variations of $G$. expansa CI $\left(r^{2}=0.54 ; p<0.0001\right)$ in LoayLoboc River (Table 2).

The hardiness and growth of bivalve species is a biological consideration in determining its potential for cultivation (Gosling, 2003). The $G$. expansa population in Loay-Loboc River has relatively longer life span compared with other tropical bivalves (Mattos \& Cardoso, 2012; Ocaña, 2014). It even lived longer compared to other Polymesoda (Geloina) species (Dolorosa \& Dangan-Galon, 2014; Yahya et al., 2018; Ransangan et al., 2019) and cultivable bivalve species (Lee, 1985; Thomas \& Nasser, 2009). It has been reported that stress resistance is reliably associated with longevity in bivalve species (Treaster et al., 2015). This suggests that the clam is tough and resilient in tropical environment, which is its known territory (Argente, 2016). Likewise, the results of this study showed fast growth rates of the clams for the first two years of existence, which is comparable with that of cultured bivalves such as Perna viridis and Paphia malabarica (AlBarwani et al., 2007; Thomas \& Nasser, 2009). The $\mathrm{K}$ estimate in this study is higher than in some bivalve species (Colakoglu \& Palaz, 2014; Hemachandra et al., 2017) which suggests that $G$. expansa in Loay-Loboc River will attain its asymptotic length faster. Sturdy and fast- growing bivalves are normally selected for aquaculture (Lucas \& Beninger, 1985).

This study showed a positive allometric growth of the $G$. expansa population in LoayLoboc River. This implies faster weight growth as compared with the growth in length of the clams. Weight growth of the clams can be attributed to the increase in soft tissue weight and the thickening of the shell. Increase in soft tissue weight indicates the good quality of the meat produced, which is a preferred trait in bivalve aquaculture (Yildiz et al., 2011). Changes in shell morphology (i.e. thickening of the shell) of Geloina species were influenced by the environmental conditions of their habitat (Morton, 1976; Bishop \& Hackney, 1987; Gimin et al., 2004). Such changes in shell morphology make these bivalves resilient to predation, erratic weather disturbances and anthropogenic perturbations. Resilience to adverse environmental conditions is a biological characteristic of potential aquaculture species (Doubleday, 2013).

The mortality and exploitation parameters of the $G$. expansa population in Loay-Loboc River showed that the clam bed is overexploited. This is also the case for other Polymesoda (Geloina) species in various regions (Rueda \& Urban, 1998; Dolorosa \& Dangan-Galon, 2014; Yahya et al., 2018; Ransangan et al., 2019). The overharvesting of these clams is not sustainable and will lead to the collapse of the fishery and of the natural population as exhibited in other bivalves (Brazeiro \& Defeo, 1999; Argente \& Estacion, 2014). It also appeared that selective fishing pressure is apparent in $G$. expansa clam bed. Given that $87 \%$ of the samples collected

Table 2: Stepwise multiple regression analysis of $G$. expansa population condition index (CI) with water temperature and salinity in Loay-Loboc River

\begin{tabular}{lccccc}
\hline \multicolumn{1}{c}{ Parameter } & $\begin{array}{c}\text { Standard } \\
\text { Estimate }(\boldsymbol{\beta})\end{array}$ & $\begin{array}{c}\text { Standard } \\
\text { Error }\end{array}$ & $\begin{array}{c}\text { Parameter } \\
\text { Estimate (B) }\end{array}$ & $\begin{array}{c}\text { Standard } \\
\text { Error }\end{array}$ & P-level \\
\hline Intercept & & & 342.5398 & 106.8233 & 0.003916 \\
Water Temperature & -0.325251 & 0.141705 & -9.2643 & 4.0362 & 0.031172 \\
Salinity & 0.682038 & 0.141705 & 7.0615 & 1.4671 & 0.000074 \\
\hline
\end{tabular}

$n=26 ; r^{2}=0.54 ; P<0.0001$ 
are less than $61 \mathrm{~mm}$, it seemed that larger individuals are the target of the fishery. Largesized or adult clams are a potential parent stock for new recruits (Argente \& Estacion, 2014). As the parent stock starts to increase in size, recruitment also increases (Gayanilo \& Pauly, 1997). If there is too much fishing pressure on large-sized $G$. expansa in the Loay-Loboc River, the whole population may deteriorate. The development of aquaculture techniques for G. expansa in Loay-Loboc River will aid in the conservation and management of the natural stocks.

The observed recruitment pattern and monthly mean CI of $G$. expansa population in the river suggest that recruitment and spawning of the clams were year-round. These reproductive characteristics are preferred in selecting bivalve species for aquaculture (Soria et al., 2014). The bimodal recruitment peaks observed from the $G$. expansa population was similar with other bivalves (Amin et al., 2005; Del NorteCampos \& Villarta, 2010). The CI of G. expansa population in Loay-Loboc River was used to describe the reproductive activities of the clams, elucidating the spawning season. It appeared that there were two peaks of spawning events for $G$. expansa, which complements the recruitment pattern on an annual basis. It appeared that the offspring produced from the spawning activities were recruited in the population during the peak of recruitment. Similar cases were reported in other bivalves (Laudien et al., 2001; Kraeuter et al., 2005). Moreover, the variations in monthly CI were significantly predicted by the changes in water temperature and salinity. The results suggested that increase in temperature and decrease in salinity may trigger spawning. These may explain the peak of spawning activities in the dry months of March and April, where the temperature is highest as observed in this study. Likewise, peaked spawning activities observed during the wet months of September to November may be attributed to lower salinity during the rainy season. These data will be useful for the development of hatchery techniques for G. expansa.

\section{Conclusion}

The present study suggests that natural populations of $G$. expansa in Loay-Loboc River are sturdy and fast-growing mud clams. The spawning and recruitment in the population is year-round. G. expansa is an emerging species that needs to be protected and managed. In this time of climate change and rising human population, the search for new and better adapted species for aquaculture is deemed necessary. The biological attributes of $G$. expansa in its natural environment makes it a potential candidate species for aquaculture. Development of culture techniques for this bivalve species will aid in the conservation and management of natural populations in central Philippines.

\section{Acknowledgements}

The authors would like to thank Mr Henry Palaca for his assistance during field sampling. The scholarship provided by DOST-PCAARRD to FA Argente is highly appreciated. This is an aquatic science contribution of USC and PSUCHANOS.

\section{References}

Adjei-Boateng, D., \& Wilson, J. G. (2012). Population dynamics of the freshwater clam Galatea paradoxa from the Volta River, Ghana. Knowledge and Management of Aquatic Ecosystems, 405(9). doi:10.1051/ $\mathrm{kmae} / 2012017$.

Ahmed, N., \& Diana, J. S. (2015). Threatening "white gold": impacts of climate change on shrimp farming in coastal Bangladesh. Ocean and Coastal Management, 114, 4252.

Al-Barwani, S. M., Arshad, A., Amin, S. M. N., Japar, S. B., Siraj, S. S., \& Yap, C. K. (2007). Population dynamics of the green mussel Perna viridis from the high spatfall coastal water of Malacca, Peninsular Malaysia. Fisheries Research, 84, 147-152.

Amin, S. M. N., Halim, M. A., Barua, M., Zafar, M., \& Arshad, A. (2005). Population 
dynamics and exploitation level of greenlipped mussel (Perna viridis) using FiSAT from the offshore island of the Cox's Bazar Coast of Bangladesh. Pertanika Journal of Tropical Agricultural Science, 28(2), 103109.

Argente, F. A. T., Cesar, S. A., \& Dy, D. T. (2014). High turbidity affects filtration rate and pseudofaeces production of the mud clam Polymesoda erosa (Solander 1786) (Bivalvia: Corbiculidae). Biotropia, 21(2), 71-81.

Argente, F. A. T., \& Estacion, J. S. (2014). Effect of different harvesting practices on the dynamics of Paphia textile (Gmelin 1792) (Bivalvia: Veneridae) populations at two sites in Zamboanga del Norte, southern Philippines. Environmental and Experimental Biology, 12, 113-120.

Argente, F. A. T., \& Ilano, A. S. (2015). Susceptibility of some pathogenic microbes to soft tissue extract of the mud clam, Polymesoda expansa (Bivalvia: Corbiculidae). The Experiment, 30(2), 1984-1990.

Argente, F. A. T. (2016). Bivalve superpower: the global invasion of corbiculid clams. Annual Research and Review in Biology, 10(3). doi:10.9734/ARRB/2016/26448.

Bayen S., Wurl, O., Karuppiah, S., Sivasothi, N., Lee, H. K., \& Obbard, J. P. (2005). Persistent organic pollutants in mangrove food webs in Singapore. Chemosphere, 61, $303-313$.

Bene, C., Arthur, R., Norbury, H., Allison E. H., Beveridge, M., Bush, S., Campling, L., Leschen, W., Little, D., Squires, D., Thilsted, S. H., Troell, M., \& Williams, M. (2016). Contribution of fisheries and aquaculture to food security and poverty reduction: Assessing the current evidence. World Development, 79, 177-196.

Bishop, T. D., \& Hackney C. T. (1987). A comparative study of the mollusc communities of two oligohaline intertidal marshes: spatial and temporal distribution of abundance and biomass. Estuaries, 10(2), 141-152.

Brazeiro, A., \& Defeo, O. (1999). Effects of harvesting and density dependence on the demography of sandy beach populations: the yellow clam Mesodesma mactroides of Uruguay. Marine Ecological Progress Series, 182, 127-135.

Chuan, O. M., Kamaruzaman M. I., Chuen, Y. J., Yunus, K. B., \& Bidai, J. (2017). Metals contamination using Polymesoda expansa (marsh clam) as bio-indicator in Kelantan River, Malaysia. Malaysian Journal of Analytical Sciences, 21(3), 597-604.

Colakoglu, S., \& Palaz, M. (2014). Some population parameters of Ruditapes philippinarum (Bivalvia, Veneridae) on the southern coast of the Marmara Sea, Turkey. Helgoland Marine Research, 68, 539-548.

Corte, G. N., Yokoyama, L. Q., Coleman, R. A., \& Amaral, A. C. Z. (2015). Population dynamics of the harvested clam Anomalocardia brasiliana (Bivalvia: Veneridae) in Cidade Beach, south-east Brazil. Journal of the Marine Biological Association of the United Kingdom. doi:10.1017/S0025315415000156

D'Abramo, L. R., \& Slater, M. J. (2019). Climate change: response and role of global aquaculture. Journal of the World Aquaculture Society. doi:10.1111/ jwas. 12643.

Del Norte-Campos A. G. C., \& Villarta, K. A. (2010). Use of population parameters in examining changes in the status of the short-necked clam Paphia undulata Born, 1778 (Mollusca, Pelecypoda: Veneridae) in coastal waters of Southern Negros Occidental. Science Diliman, 22, 53-60.

Dolorosa, R. G., \& Dangan-Galon, F. (2014). Population dynamics of the mangrove clam Polymesoda erosa (Bivalvia: Corbiculidae) in Iwahig, Palawan, Philippines. International Journal of Fauna and Biological Studies, 1(6), 11-15. 
Doubleday, Z. A., Clarke, S. M., Li, X., Pecl, G. T. Ward, T. M., Battaglene, S., Frusher, S., Gibbs, P. J., Hobday, A. J., Hutchinson N., Jennings, S. M., \& Stoklosa, R. (2013). Assessing the risk of climate change to aquaculture: A case study from southeast Australia. Aquaculture Environment Interactions, 3, 163-175.

Dworjanyn, S. A., \& Byrne, M. (2018). Impacts of ocean acidification on sea urchin growth across the juvenile to mature adult lifestage transition is mitigated by warming. Proceedings of the Royal Society B: Biological Sciences, 285. doi:10.1098/ rspb.2017.2684.

Food and Agriculture Organization of the United Nations. (2020). Fisheries and aquaculture software. FISAT II - FAO-ICLARM Stock Assessment Tool. In FAO Fisheries and Aquaculture Department [online]. Rome. Updated 24 February 2020. [Cited 13 June 2020]. http://www.fao.org/fishery/

Fauzan, M., Bakti, D., Susetya, I. E., \& Desrita. (2018). Growth and exploitation rate of Anadara gubernaculum (Reeve, 1844) Arcidae Family in Asahan Aquatic of North Sumatra. IOP Conference Series: Earth and Environmental Science, 122. doi:10.1088/1755-1315/122/1/012105.

Frona, D., Szenderak, J., \& Harangi-Rakos, M. (2019). The challenge of feeding the world. Sustainability, 11. doi:10.3390/su11205816.

Gayanilo, F. C. Jr., \& Pauly D. (1997). FAOICLARM stock assessment tools (FiSAT), reference manual. FAO Computerized Information Series (Fisheries), No. 8. Rome: Food and Agriculture Organization of the United Nations. 262 p.

Gimin, R., Mohan, R., Thinh, L. V., \& Griffiths A. D. (2004). The relationship of shell dimensions and shell volume to live weight and soft tissue weight in the mangrove clam, Polymesoda erosa (Solander, 1786) from Northern Australia. NAGA, WorldFish Center Quarterly, 27(3 and 4), 32-35.
Gosling, E. M. (2003). Bivalve molluscs: Biology, ecology and culture. Oxford, United Kingdom: Fishing News Books.

Hariyadi, Zainuri, M., Afiati, N., \& Lachmuddin, S. (2017). Population dynamics of Potamocorbula faba Hinds, 1843 (Bivalvia: Corbulidae) in Permisan Bay, Sidoarjo, Indonesia. AACL Bioflux, 10(3), 543-550.

Hall, G. M. (2015). Impact of climate change on aquaculture: the need for alternative feed components. Turkish Journal of Fisheries and Aquatic Sciences, 15, 569-574.

Hemachandra., Tenjing S. Y., \& Thippeswamy, S. (2017). Population dynamics of the Asian green mussel Perna viridis (L.) from St. Mary's islands off Malpe, India. Indian Journal of Geo-Marine Sciences, 46(8), 1659-1666.

Hiong, K. C., Peh, W. Y. X., Loong, A.M., Wong, W. P., Chew, S. F., \& Ip, Y. K. (2004). Exposure to air, but not seawater, increases the glutamine content and the glutamine synthetase activity in the marsh clam Polymesoda expansa. The Journal of Experimental Biology, 207, 4605-4614.

Ilano A. S., Sotto F. B., \& Juario, J. V. (2007). Sexual maturity and reproductive cycle of Paphia textilis (Gmelin, 1791) (Bivalvia: Veneroidea) off Sillon waters, Bantayan Island, Cebu, Philippines. Journal of Aquatic Science, 4, 89-103.

Kraeuter, J. N., Buckner, S., \& Powell E. N. (2005). A note on a spawner-recruit relationship for a heavily exploited bivalve: The case of northern Quahogs (hard clams), Mercenaria mercenaria in Great South Bay, New York. Journal of Shellfish Research, 24(4), 1043-1052.

Laudien, J., Brey, T., \& Arntz, W.E. (2001). Reproduction and recruitment patterns of the surf clam Donax serra (Bivalvia, Donacidae) on two Namibian sandy beaches. South African Journal of Marine Science, 23(1), 53-60. 
Lee, S. Y. (1985). The population dynamics of the green mussel, Perna viridis (L.) in Victoria Harbour, Hong Kong - dominance in a polluted environment. Asian Marine Biology, 2, 107-118.

Lomovasky, B. J., Brey, T., \& Morriconi, E. (2005). Population dynamics of the venerid bivalve Tawera gayi (Hupe, 1854) in the Ushuaia Bay, Beagle Channel. Journal of Applied Ichthyology, 21, 64-69.

Lucas, A., \& Beninger, P. G. (1985). The use of physiological condition indices in marine bivalve aquaculture. Aquaculture, 44(3), 187-200.

Mattos, G., \& Cardoso, R. S. (2012). Population dynamics of two suspension-feeding bivalves on a sheltered beach in southeastern Brazil. Helgoland Marine Research, 66, 393-400.

Misselhorn, A., Aggarwal, P., Ericksen, P., Gregory, P., Phathanothai, L.H., Ingram, J., \& Wiebe, K. (2012). A vision for attaining food security. Current Opinion in Environmental Sustainability, 4, 7-17.

Morton, B. (1976). The biology and functional morphology of the Southeast Asian mangrove bivalve, Polymesoda (Geloina) erosa (Solander, 1786) (Bivalvia: Corbiculidae). Canadian Journal of Zoology, 54, 482-500.

Ocaña, F. A. (2014). Growth and production of Donax striatus (Bivalvia: Donacidae) from Las Balsas Beach, Gibara, Cuba. Revista de Biologia Tropical, 63(3), 639-646.

Petetta, A., Bargione G., Vasapollo C., Virgili, M., \& Lucchetti A. (2019). Length-weight relationships of bivalve species in Italian razor clam Ensis minor (Chenu, 1843) (Mollusca: Bivalvia) fishery. The European Zoological Journal, 86(1), 363-369.

Pradeepkiran, J. A. (2019). Aquaculture role in global food security with nutritional value: A review. Translational Animal Science, 3, 903-910.
Rahim, A. A., Idris, M. H., Kamal, A. H. M., Wong, S. K., \& Arshad, A. (2012). Analysis of the condition index in Polymesoda expansa (Mousson 1849). Pakistan Journal of Biological Sciences, 15, 629-634.

Ransangan, J., Soon, T. K., \& Duisan, L. (2019). Population dynamics of marsh clam, Polymesoda spp. (Bivalvia: Corbiculidae) in Marudu Bay, Malaysia. AACL Bioflux, 12(2), 395-403.

Reid, G. K., Gurney-Smith, H. J., Marcogliese, D. J., Knowler, D., Benfey, T., Garber, A. F., Forster, I., Chopin, T., Brewer-Dalton, K., Moccia, R. D., Flaherty, M., Smith, C. T., \& De Silva, S. (2019). Climate change and aquaculture: considering biological response and resources. Aquaculture Environment Interactions, 11, 569-602.

Rueda, M., \& Urban, H. J. (1998). Population dynamics and fishery of the fresh-water clam Polymesoda solida (Corbiculidae) in Cienaga Poza Verde, Salamanca Island, Colombian Caribbean. Fisheries Research, $39,75-86$.

Solis, M. A., Ballesteros, M., \& Riascos, J. M. (2019). The early life history transitions of the bivalve Aulacomya atra from the Humboldt Current System off Peru are affected by human exploitation and modulated by El Niño-La Niña cycle. Frontiers in Marine Science, 6. doi:10.3389/ fmars.2019.00496.

Soria, G., Lavin, M. F., \& Cudney-Bueno, R. (2014). Spat availability of commercial bivalve species recruited on artificial collectors from the northern Gulf of California: Seasonal changes in species composition. Aquaculture Research, 46(12). doi:10.1111/are.12435.

Sparre, P., \& Venema S. C. (1998). Introduction to tropical fish stock assessment, Part 1: Manual. Rome, Italy. Food and Agriculture Organization of the United Nations.

Steeves, L. E., Filgueira, R., Guyondet, T., Chasse, J., \& Comeau, L. (2018). Past, 
present, future: Performance of two bivalve species under changing environmental conditions. Frontiers in Marine Science, 5. doi:10.3389/fmars.2018.00184.

Stern-Pirlot, A., \& Wolff, M. (2006). Population dynamics and fisheries potential of Anadara tuberculosa (Bivalvia: Arcidae) along the Pacific coast of Costa Rica. Revista de Biologia Tropical, 54(1), 87-99.

Thomas S., \& Nasser, M. (2009). Growth and population dynamics of short-neck clam Paphia malabarica from Dharmadom Estuary, North Kerala, southwest coast of India. Journal of the Marine Biological Association of India, 51(1), 87-92.

Treaster, S. B., Chaudhuri, A. R., \& Austad, S. N. (2015). Longevity and GAPDH stability in bivalves and mammals: A convenient marker for comparative gerontology and proteostasis. PLOS ONE, 10(11). doi:10.1371/journal.pone.0143680.
United Nations, Department of Economic and Social Affairs, Population Division. (2019). World Population Prospects 2019: Highlights (ST/ESA/SER.A/423). https:// population.un.org/wpp/Publications/Files/ WPP2019_Highlights.pdf.

Yahya, N., Idris, I., Rosli, N. S., \& Bachok, Z. (2018). Population dynamics of mangrove clam, Geloina expansa (Mousson, 1849) (Mollusca, Bivalvia) in a Malaysian Mangrove System of South China Sea. Journal of Sustainability Science and Management, 13(5), 203-216.

Yildiz, H., Berber, S., Acarli, S., \& Vural, P. (2011). Seasonal variation in the condition index meat yield and biochemical composition of the flat oyster Ostrea edulis (Linnaeus, 1758) from the Dardanelles, Turkey. Italian Journal of Animal Science, 10(1). doi:10.4081/ijas.2011.e5. 